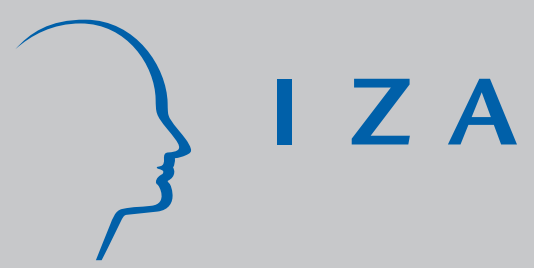

IZA DP No. 652

How Do Parents Raise the Educational Attainment of Future Generations?

Erik Plug

November 2002 


\title{
How Do Parents Raise the Educational Attainment of Future Generations?
}

\author{
Erik Plug \\ University of Amsterdam, Tinbergen Institute \\ and IZA Bonn
}

\section{Discussion Paper No. 652 \\ November 2002}

\author{
IZA \\ P.O. Box 7240 \\ D-53072 Bonn \\ Germany \\ Tel.: +49-228-3894-0 \\ Fax: +49-228-3894-210 \\ Email: iza@iza.org
}

This Discussion Paper is issued within the framework of IZA's research area The Future of Labor. Any opinions expressed here are those of the author(s) and not those of the institute. Research disseminated by IZA may include views on policy, but the institute itself takes no institutional policy positions.

The Institute for the Study of Labor (IZA) in Bonn is a local and virtual international research center and a place of communication between science, politics and business. IZA is an independent, nonprofit limited liability company (Gesellschaft mit beschränkter Haftung) supported by the Deutsche Post AG. The center is associated with the University of Bonn and offers a stimulating research environment through its research networks, research support, and visitors and doctoral programs. IZA engages in (i) original and internationally competitive research in all fields of labor economics, (ii) development of policy concepts, and (iii) dissemination of research results and concepts to the interested public. The current research program deals with (1) mobility and flexibility of labor, (2) internationalization of labor markets, (3) welfare state and labor market, (4) labor markets in transition countries, (5) the future of labor, (6) evaluation of labor market policies and projects and (7) general labor economics.

IZA Discussion Papers often represent preliminary work and are circulated to encourage discussion. Citation of such a paper should account for its provisional character. A revised version may be available on the IZA website (www.iza.org) or directly from the author. 
IZA Discussion Paper No. 652

November 2002

\title{
ABSTRACT \\ How Do Parents Raise the Educational Attainment of Future Generations?*
}

The problem with most intergenerational mobility estimates is that unmeasured and inherited abilities prevent us from drawing inferences. In this paper we estimate the intergenerational mobility of schooling and exploit differences between adopted and own birth children to obtain genetically unbiased estimates. Our results provide a much better insight on whether parents (and policy makers) can actually stimulate the educational attainment of future generations. Controlling for inherited abilities and assortative mating we find that the association between mother's (but not father's) and child schooling disappears.

JEL Classification: $\quad$ I21, J13, J24

Keywords: intergenerational mobility of schooling, inherited abilities, adoption

\author{
Erik Plug \\ Department of Economics and Econometrics \\ University of Amsterdam \\ Roetersstraat 11 \\ 1018 WB Amsterdam \\ The Netherlands \\ Tel.: +31205254311 \\ Fax: +31205254310 \\ Email: plug@fee.uva.nl
}

\footnotetext{
* This research is part of the NOW priority program on schooling, labour market performance and economic development. Support for collection and dissemination of data from the Wisconsin Longitudinal Study has been provided by the National Institute on Aging (AG-9775), the National Science Foundation (SBR-9320660), the Spencer Foundation, and the Center for Demography and Ecology and the Vilas Estate Trust at the University of Wisconsin-Madison. We further thank Anders Björklund, Mikael Lindahl, Hessel Oosterbeek and Wim Vijverberg for helpful comments.
} 


\section{Introduction}

In a recent paper Behrman and Rosenzweig (2002) present empirical evidence that contradicts the conventional wisdom that maternal schooling has a bigger effect on the child's schooling than that of her husband. ${ }^{1}$ They consider the impact of parental schooling on child schooling in the presence of unmeasured ability and assortative mating. Using twin data, they come to the surprising conclusion that the mother's schooling has little if any impact on the schooling of her child, holding everything else (including unobserved ability factors of either mother or father) constant.

Their findings - we reason- must be bolstered with further support. In this paper we consider the effects of unobserved inherited abilities on the child's schooling, but instead of twinning, we obtain identification from adopted children. Adopted children share only their parents' environment and not their parents' genes. Therefore any relation between the schooling of adoptees and their adoptive parents is driven by the influence parents have on their children's environment, and not by parents passing on their genes. Controlling for inherited abilities and assortative mating we find that the association between mother's (but not father's) and child schooling disappears. Our findings are consistent with the twin results of Behrman and Rosenzweig (2002, BR henceforth).

In the following, we compare identification strategies with adopted children and twin mothers in Section 2. In Section 3 we provide a brief description of the Wisconsin Longitudinal Survey. In Section 4 the parameter estimates are presented and compared to the estimates reported in two recent adoption studies in the field. Section 5 further explores to what extent our findings are subject to contradictory interpretations. And Section 6 highlights the implications and conclusions of this study.

\section{A simple mobility model}

We use a reduced form intergenerational mobility model that is consistent with models of household resource allocations where both parents have an effect on their child's schooling

$$
S_{i}^{c}=\delta_{1} S_{i}^{m}+\delta_{2} S_{i}^{f}+\Gamma_{1} h_{i}^{m}+f_{i}^{m}+\Gamma_{2} h_{i}^{f}+f_{i}^{f}+\epsilon_{i}^{c} .
$$

Subscript $i$ indexes the family in which the child is raised, $S_{i}^{c}$ indicates the child's schooling, $S_{i}^{m}$ is the schooling of the mother, $S_{i}^{f}$ is the schooling of the father, the $h$ 's are the unobserved heritable endowments of both parents, the $f$ 's are the endowments that express the child-rearing talents of both parents, and $\epsilon_{i}^{c}$ is a child-specific characteristic. The heritable endowments are passed on

\footnotetext{
1 "The human capital of the mother is usually more closely related to the attainment of the child than is that of the father." (Haveman and Wolfe, 1995 p.1855)
} 
genetically and common to the parents' own birth children. The child-rearing endowments, however, are common to all children in the family. ${ }^{2}$ We will focus our attention on the parameter $\delta_{1}$ that measures the effect of the mother's schooling on that of her child. The maternal effect should capture the impact that her schooling has on the quality and quantity of time, goods and money she devotes to her child net of the effects that are genetically driven.

In this paper we propose an adoption strategy to identify $\delta_{1}$. The advantage of using adoptees is that these children do not share their parents' genes. If we think of adoption as a natural experiment where children given up for adoption are randomly placed in their adoptive families, we may safely assume that the $\Gamma$ coefficients are zero. For adoptees the schooling function in (2.1) is written down as

$$
S_{i}^{c}=\delta_{1} S_{i}^{m}+\delta_{2} S_{i}^{f}+f_{i}^{m}+f_{i}^{f}+\epsilon_{i}^{c} .
$$

By assumption the bias caused by the parents' heritable endowments $h$ are eliminated, however, the inborn child-rearing talents of both parents remain. ${ }^{3}$ There are two reasons for these unobserved child-rearing talents to be correlated with the mother's schooling. If better educated mothers have better mothering skills to begin with, and if better educated mothers choose their marriage partner for his parenting skills, the effect of the mother's schooling on that of her child is overestimated.

And what about twinning? With monozygotic twin mothers, identical in their inborn endowments but different in their amounts of schooling, BR obtain identification by differencing the schooling functions of the mothers' children

$$
\begin{aligned}
& S_{i}^{c}-S_{j}^{c}= \\
& \quad \delta_{1}\left[S_{i}^{m}-S_{j}^{m}\right]+\delta_{2}\left[S_{i}^{f}-S_{j}^{f}\right]+\Gamma_{2}\left[h_{i}^{f}-h_{j}^{f}\right]+\left[f_{i}^{f}-f_{j}^{f}\right]+\epsilon_{i}^{c}-\epsilon_{j}^{c} .
\end{aligned}
$$

By taking school differences between nephews and nieces the biases caused by the mothers' heritable and inborn child-rearing endowments $h$ and $f$ are eliminated, but differences between their fathers' heritable and child-rearing endowments are still there and need to be taken into account in order to achieve identification. ${ }^{4}$ If not, the effect of the mother's schooling is biased upwards if mothers with more schooling marry their partner for his favorable endowments and fathering skills.

${ }^{2}$ This intergenerational mobility model is almost identical to the model used by BR with the exception that we allow fathers to have child-rearing endowments.

${ }^{3}$ Without random assignment, the relation between the mother's schooling and that of her child is no longer independent of inherited abilities. In Section 5 we relax the assumption of random assignment, allow $\Gamma$ to be nonzero and explain why this potential selection effect may work in our advantage when interpreting the absence of maternal schooling effects.

${ }^{4} \mathrm{As}$ a remedy for the missing endowments BR propose to include different measures for the fathers' heritable endowments, and subsequently test the sensitivity of their estimate of $\delta_{1}$. They further (but only implicitly) assume that the father's child-rearing endowments are uncorrelated with the mothers' schooling. 
To more easily compare these adoption and twin strategies, we ignore the role of assortative matching, and consider single-mother families, and apply least squares to the previous intergenerational schooling relations. In the adoption case, the probability limit of the estimator $\widehat{\delta}_{1}$ equals

$$
\operatorname{plim} \widehat{\delta}_{1 a d o p t}=\delta_{1}+\operatorname{cov}\left(S_{i}^{m}, f_{i}^{m}\right) / \operatorname{var}\left(S_{i}^{m}\right) .
$$

Again, if better educated mothers are better mothers to begin with, $\operatorname{cov}\left(S_{i}^{m}, f_{i}^{m}\right)$ is positive and $\delta_{1}$ is bounded from above. In the twin case, the probability limit for the estimator becomes

$$
\operatorname{plim} \widehat{\delta}_{1 \text { twin }}=\delta_{1} .
$$

Under these simplifying conditions, these equations make transparent that the twin strategy eliminates the inborn child-rearing bias. Yet, between-twins estimation is not necessarily the better approach. Two reasons apply. First, twinning is more sensitive to measurement error. If the mother's schooling is measured with error, differencing amplifies the downward bias that comes from measurement error. ${ }^{5}$ Second, twinning does not a priori suffer less from the unobserved heterogeneity that remains after differencing the mother's schooling. Since monozygotic twin mothers are almost but not exactly identical, the estimate of $\delta_{1}$ may still be biased if differences in early childhood experiences are responsible for differences in both their schooling and child-rearing talents. ${ }^{6}$ If variation in these remaining mothering skills driven by early childhood experiences takes up a relatively larger share of the between-twin variation than it does of the variation among adoptees, it is possible that resulting inconsistencies are aggravated with twinning (Griliches, 1979; Bound and Solon, 1999).

It thus seems that both approaches fail in finding the perfect identification for the effect of changing the mother's schooling on that of her child. This does not mean, however, that the estimation of (2.2) on a sample of adoptees or (2.3) on a sample of nephews and nieces with twin mothers is without value. Our approach, just like the twin approach, can be credited for obtaining genetically unbiased estimates. Moreover, it is interesting to have a complementary approach that describes the same process of intergenerational mobility of schooling in the presence of inherited ability and assortative mating.

${ }^{5}$ When BR control for measurement error, they keep finding that the mother's schooling has no impact on the schooling of her child.

${ }^{6}$ We think of differences that emerge in the womb and differences that occur after birth during early childhood. There are differences between conception and birth resulting in observed birth weight differences of twins (Behrman, Rosenzweig and Taubman, 1994). After birth some differences happen more or less at random (one twin breaks her arm while the other twin does not) and other differences occur more systematically (some parents separate their twins and put them in different schools, and some twins feel the need to differentiate themselves). Bound and Solon (1999) explain in much more detail how twins with identical genetic endowments end up to be different. 


\section{Data}

We have at our disposal a U.S. data set, the Wisconsin Longitudinal Survey, that contains detailed multi-generational information about families. Data collection started in 1957 on a group of high school male and female students in Wisconsin all born around 1939. Information was gathered about their IQ, family background, and so on. In 1964, 1975, and 1992, the same students were contacted again and information was collected about their school careers, labor market status, family conditions, and the school careers of their children. For these children it is recorded whether they are their parents' own offspring or whether they are adopted. ${ }^{7}$

Of particular interest for the present study, a set of questions targeted the educational attainment of the respondents' children. Respondents, both men and women, were asked to list for each child the highest grade or year of regular school that child ever attended, whether (s)he completed this grade or year, and whether (s)he attended a regular school in the last 12 months. From the information on educational attainment we create two variables. "Years of schooling" equals the number of years nominally required for the highest level of education that the child completed. "College education" indicates whether or not a child completed more than 16 years of education. Children who were still in school constitute censored observations and will be treated accordingly in our empirical analysis; this is the case for about 25 percent of all own birth children and about 40 percent of all adopted children in our sample. Descriptive statistics on all children in the WLS sample appear in Table 1.

\section{Results}

In Table 2 we present our intergenerational mobility estimates of schooling. The structure of Table 2 is as follows. The first panel presents estimates of censored regressions on years of education. The second panel presents estimates of probit regressions on college education where children younger than 23 with no college education are excluded from the analysis. ${ }^{8}$ We run separate regressions on a sample of own birth children and on a sample of adoptees. All regressions include individual controls for the child's age, gender, and the number of siblings. We do not report these parameters. ${ }^{9}$ Instead, we focus our attention on the

${ }^{7}$ For an extended data description we refer to Plug and Vijverberg (2002, 2003). For more detailed information on the WLS data we refer to Sewell and Hauser (1992).

${ }^{8}$ The age limit of 23 years is selected in recognition of potential selectivity effects. If we do not account for those children who were too young to be graduated from their college education, we end up with a sample where young children with less education are overrepresented.

${ }^{9}$ Other than the child's gender and current age, we have no information on things like age at adoption or race. We have experimented with alternative variable specifications including measures on the child's relative age (whether the child is the oldest or the youngest child in the family), sibling composition (whether or not own birth and adopted children are raised together within one family), and gender of respondent. The parental schooling estimates we 
effects of the schooling of parents have on the schooling of their children using different specifications. The sample we use consists of all adopted children, which means that some of these children are raised within the same family. The computation of the standard errors takes the family correlations in the error term into account.

We begin with the schooling estimates that are obtained from a sample using children who are their parents' own biological offspring. In columns (1) and (2) we include the mother's and father's schooling as separate regressors. As expected, we find that higher educated parents raise the number of years of schooling of their own birth children, and that the influence of the mother's schooling is more important than that of her husband. The effect of parental schooling as it is estimated represents both the direct transfer from the given parent and the indirect transfer from the other parent, which is due to assortative mating and the ensuing correlation of the parents' schooling, or on something that correlates with schooling. In our sample we find a correlation between the parents' schooling of 0.544 which illustrates the non randomness of matching. To quantify the transmission effects due to assortative mating, we include mother's and father's schooling simultaneously, and thus allow the schooling of both parents to have a separate effect on their child's schooling. In column (3) we find that the maternal schooling effect is most sensitive to the inclusion of her partner's schooling. With her husband's schooling, the partial effect of mother's schooling is reduced by almost a half. The partial schooling effects of both parents are significantly positive and almost identical. Inclusion of family income as an additional control variable does not substantially change the parental schooling coefficients.

The fundamental problem with the interpretation of intergenerational mobility estimates thus far is that it ignores the strong correlation of parental schooling with unobserved ability. Since better educated parents are on average better endowed than less educated parents, they also tend to produce children who do well in school by virtue of superior genes. As economists we are not so much interested in effects that are genetically driven. In essence genes are automatically passed on from parent to child without regards for incentives (Grawe and Mulligan, 2002). We would rather have information on that part of the mother's and father's schooling that is uncontaminated with family genes but still responsible for the school success of future generations.

In the next four columns we remove the influence of the family genes by estimating the previous intergenerational mobility specifications on a sample of adoptees. We find in columns (1) and (2) that the effects of parental schooling fall significantly, but that the influences of the mother's and father's years of schooling are still statistically significant, positive and equally important. The schooling estimates for own birth and adopted children are statistically different. These results show that part of the child's schooling is inherited, but that it is obtained are very similar to the ones we present in this paper. 
only the smaller part. Provided that our model is correctly specified, we find that family genes are responsible for about 50 percent of the impact of mother's schooling and about 30 percent of the impact of father's schooling on that of their children. In column (3) we take into account the intergenerational effect of the marriage partner. As before, we find that the mother's schooling effect on her child's schooling is cut in half, which -we reason- is due to assortative matching among partners on schooling or on something that correlates with schooling. ${ }^{10}$ But this time her schooling effect lacks statistical significance. With the additional effects of family income in column (4) the maternal coefficient falls somewhat further. The estimate of the effect of father's schooling on that of his child, however, is rather insensitive to the inclusion of mother's schooling (and family income). In contrast to maternal schooling effects, paternal schooling effects remain positive and statistically significant in all specifications.

In the second panel of Table 2 we switch the dependent variable to whether or not the child is graduated from college. We also replace the parental years of schooling measures for whether or not the mother or father completed their college education. With college education our findings are very similar to those previously reported. The coefficients which represent partial derivatives show that (i) children with adoptive mothers and fathers with a college degree experience a significant higher chance of graduating from college themselves; (ii) that for the intergenerational mobility of schooling family genes still matter but that it is the larger part of the parents' schooling that contributes to a better family environment for children to graduate ${ }^{11}$; and (iii) that when the schooling measures of both partners are included, her partial effect of having a college education almost disappears where his partial effect of having a college education remains positive and statistically significant.

In the field of economics Sacerdote (2000) and Björklund and Richardson (2001) also investigate the mobility relation between the parents' schooling and that of their child using samples with adopted and own birth children. ${ }^{12}$ With a rather small sample of 170 adoptees Sacerdote (2000) finds positive and statistically significant schooling effects of both parents when mother's and father's schooling are included as separate regressors. Also similar to our findings is that the effect of mother's schooling on that of her adopted child is the most sensitive to the inclusion of her partner's schooling. He finds that the partial effect of maternal schooling is cut in half. The difference is, however, that her estimated schooling effect remains positive and statistically significant with

\footnotetext{
${ }^{10}$ Also for parents who adopt we find that the reduction closely corresponds to the correlation between their amounts of schooling of 0.502 .

${ }^{11}$ With college education, we find that about 45 percent of the mother's schooling and 10 percent of the father's schooling is genetically transmitted.

${ }^{12}$ In a similar fashion Plug and Vijverberg (2002) analyze the WLS sample of adoptees to estimate the effect of family income on the child's schooling. In their analysis father's and mother's schooling are merely used to see whether family income effects are robust. This paper is different because of its explicit focus on the impact of the schooling of parents on that of their children.
} 
her partner's schooling included. ${ }^{13}$ With adoptees in Sweden Björklund and Richardson (2001) find the opposite and report estimates that indicate that both mother's and father's schooling have no impact at all. Our findings lie somewhere in between.

\section{$5 \quad$ Fact or fiction?}

Our results are in apparent contradiction with widely held wisdom that mother's schooling is more important for her child's schooling than that of her husband. Is it possible that we misinterpret our findings?

There is no doubt that our adoption results do not perfectly identify the effect of changing the mother's schooling on that of her child. We already showed that although our estimates are genetically unbiased, the estimated effect of the mother's schooling on that of her adopted child is probably too high because of unobserved inborn parenting skills (of both mother and her marriage partner). Possible selection can even amplify this upward bias. If adoptions are related or if adoption agencies use information on the natural mother's schooling to place children in their adoptive families, and we ignore this matching correlation, our mobility estimates are wrongfully crediting the family environment. Regardless, whether it is better parenting or selection, we don't expect them to be responsible for the maternal absence. Instead, we should rather be concerned about mechanisms that can possibly create a downward bias.

The first candidate is measurement error. It is well known that random measurement error biases any estimated effect to zero. To let this be consistent with our findings, the amount of measurement error for women's schooling has to be bigger than that for men's schooling. In samples where respondents are predominantly male, and through which information of the marriage partner is gathered, this seems a reasonable explanation. However, in our sample where the number of mothers and fathers who serve as primary respondents is about the same, it is not. In an analysis not shown in this paper, we estimated previous schooling models using only adoptive mothers who served as primary respondents in the WLS survey and found maternal schooling estimates close to zero. Hence, we do not believe that measurement error is our biggest concern.

The second candidate is heterogeneity with respect to the age adoptees meet their adoptive families. Because this age is not recorded, it is possible that the share of adoptees who were brought into their adoptive families at a later age forces the estimated impact of mother's schooling to zero. The argument is as follows. If the mother's time is an important determinant in raising her child during the preschool years, and her impact of schooling is most effective when the child is young, some adoptees in our sample fail to receive these maternal

${ }^{13}$ We are grateful to Bruce Sacerdote for running the latter specification -which was not included in his paper- especially for us. 
benefits because they are placed in their families at a later age. The problem is, however, that a similar argument is often used to explain why mother's schooling is more important than that of her husband. After all, it is mostly the mother's and not the father's time that is the primary input when raising the child when he or she is young. Because we find schooling effects of adoptive fathers that are positive and statistically significant, we do not think that children who are adopted at a later age are driving our results. ${ }^{14}$

The third candidate is that there are differences in upbringing. Case, Lin and McLanahan $(2000,2001)$ put forward the Cinderella motive where mothers favor their own offspring because of some evolutionary drive to protect their genetic material. If this is the case and mothers do as a result invest relatively less in their adopted child, the estimated effect of mother's schooling on a sample of adoptees proves not to be insightful. To get an idea how seriously differences in upbringing affect our outcomes, we consider families that adopt and compare the educational outcomes of their adopted children with and without own birth siblings. Cinderella motives would predict that adoptees with own birth siblings do relatively worse in school. Table 3 clearly shows that whether we compare means or look at regression coefficients (that are conditioned on mother's schooling), there are virtually no differences. Hence, we do not see that mothers more heavily invest in their own birth children. ${ }^{15}$

The fourth and final candidate is that children who are given up for adoption are a selective sample of children who have problems with (their) mothers. Becker (1991, p.140-141) gives a possible rationale and argues that if mothers could choose, they would rather put their problematic child up for adoption. We don't know how to remove this bias. We do know, however, that in our empirical analysis the intercept captures the potential effect that adoptees are on average more problematic than own birth children. Unless these problems correlate with mother's schooling, there will be no downward bias in the maternal schooling estimate.

In the end, we are not so much worried that measurement error, children who are adopted at a later age, or differences in upbringing lead to misinterpretations. This, in combination with the findings of $\mathrm{BR}$, give us a reason to believe that once we control for heritable ability and assortative mating the positive influence of the mother's schooling on her child's schooling has almost vanished.

\footnotetext{
${ }^{14}$ Of course, it is also possible that the mother's schooling is important when the child is young but that the father's schooling is important at a later stage of his child's life, perhaps, when financing his child's college or university education. A timing decomposition with the present data would be enlightening but is left for future research. The WLS does not provide information on the timing of adoption.

${ }^{15}$ Other studies have tested the idea of treatment differentials among adopted and own birth siblings and also found that this mechanism is essentially not observed (Plug and Vijverberg, 2002, 2003; Björklund and Richardson, 2001).
} 


\section{Concluding remarks}

In this paper we examine the impact of parental schooling on the child's schooling and use adoptees to get rid off persistency effects caused by family genes. Two results stand out.

First, we find a positive and significant impact of parents' schooling on that of adopted children, and we also find that the impact for own birth children is somewhat larger. These results suggest that once we control for unobserved but heritable ability most of the parents' schooling contributes to the family environment in which children do well in school. We are inclined to take these results seriously, despite the fact that we are aware that they are tainted by selective placements of adoptees. With data where the mechanism of assigning children to their adoptive parents is fairly random, Sacerdote $(2000,2002)$ finds rather large treatment effects that come from the parental schooling very similar to ours.

Second, we also find that especially for mothers assortative mating plays an important role in the intergenerational transmission of schooling. When we ignore assortative mating, we find that the mother's schooling exerts a positive and significant influence on the schooling of her adopted child. With assortative mating, on the other hand, we find that the mother's schooling has little if any impact on her adopted child's schooling. The influence of the father's schooling, however, is still there. These results suggest that the mother's schooling improves her child's schooling, but rather indirectly through her marriage partner.

\section{References}

Becker Gary. 1991 A treatise on the family. Enlarged edition. Harvard University Press, Cambridge, MA.

Behrman, Jere and Mark Rosenzweig. 2002. Does increasing women's schooling raise the schooling of the next generation? American Economic Review, 92, 323-334.

Behrman, Jere, Mark Rosenzweig, and Paul Taubman. 1994. Endowments and the allocation of schooling in the family and in the marriage market: The twins experiment. Journal of Political Economy, 102, 1131-1174.

Björklund, Anders and Katarina Richardson. 2001. The educational attainment of adopted children born abroad: Swedish evidence. Mimeo, University of Stockholm.

Bound, John and Gary Solon. 1999. Double trouble: On the value of twinsbased estimation of the return to schooling. Economics of Education Review, 18, 169-182. 
Case, Anne, I-Fin Lin and Sara McLanahan. How hungry is the selfish gene? Economic Journal, 110, 781-804.

Case, Anne, I-Fen Lin and Sara McLanahan. 2001. Educational attainment of siblings in stepfamilies. Evolution and Human Behavior, 22, 269-289.

Grawe, Nathan and Casey Mulligan. 2002. Economic interpretations of intergenerational correlations. Journal of Economic Perspectives, forthcoming.

Griliches, Zvi. 1979. Sibling models and data in economics: Beginnings of a survey. Journal of Political Economy, 87, 37-64.

Haveman, Robert and Barbara Wolfe. 1995. The determinants of children attainments: A review of methods and findings. Journal of Economic Literature, 33, 1829-1878.

Plug, Erik and Wim Vijverberg. 2002. Does family income matter for schooling outcomes? Using adoption as a natural experiment. Mimeo, University of Amsterdam.

Plug, Erik and Wim Vijverberg. 2003. Schooling, family background, and adoption: Is it nature or is it nurture? Journal of Political Economy, forthcoming.

Sacerdote, Bruce. 2000. The nature and nurture of economic outcomes. NBER working paper 7949 .

Sacerdote, Bruce. 2002. The nature and nurture of economic outcomes. American Economic Review Papers and Proceedings, 92, 344-348.

Sewell, William and Robert Hauser. 1992. A Review of the Wisconsin Longitudinal Study of Social and Psychological Factors in Aspiration and Achievement, 1963-1993. University of Wisconsin-Madison: Center for Demography and Ecology, Working Paper no. 92-01. 
Table 1: Means and standard deviations of selected variables in WLS sample

\begin{tabular}{|c|c|c|c|c|}
\hline & \multicolumn{2}{|c|}{ Own birth children } & \multicolumn{2}{|c|}{ Adopted children } \\
\hline Education in years & 13.577 & 2.526 & 12.686 & 2.691 \\
\hline College graduate ${ }^{a}$ & 0.375 & 0.484 & 0.274 & 0.446 \\
\hline Still in school (censored) & 0.238 & 0.426 & 0.391 & 0.488 \\
\hline Gender (daughter) & 0.491 & 0.499 & 0.490 & 0.500 \\
\hline Age & 26.638 & 4.861 & 23.955 & 5.282 \\
\hline Number of siblings & 2.860 & 1.693 & 2.200 & 1.676 \\
\hline Families with own birth and adopted children & 0.031 & 0.173 & 0.557 & 0.497 \\
\hline Education in years, father & 13.463 & 2.615 & 14.245 & 2.842 \\
\hline Education in years, mother & 12.802 & 1.671 & 13.265 & 1.934 \\
\hline College graduate, father & 0.262 & 0.440 & 0.355 & 0.479 \\
\hline College graduate, mother & 0.144 & 0.351 & 0.219 & 0.414 \\
\hline Log family income measured in 1992 & 10.939 & 0.712 & 11.121 & 0.629 \\
\hline Number of observations & 15871 & & 610 & \\
\hline
\end{tabular}

Standard deviations in italics.

${ }^{a}$ Mean and standard deviations are calculated for respectively 383 and 12721 observations. For

this variable children younger than 23 with less than 16 years of education are not included. 
Table 2: Estimates of the effects of mother's and father's schooling on children's schooling.

(1)

(2)

(3)

(4)

(1)

(2)

(3)

(4)

Dependent variable is

years of schooling:

Mother's years of schooling

0.519

$0.016^{* * *}$

Father's years of schooling

Log family income in 1992

Number of observations

15871

15871

$0.285 \quad 0.266 \quad 0.263$

$\begin{array}{lll}0.016^{* * *} & 0.016^{* * *} & 0.063^{* * *}\end{array}$

$0.290 \quad 0.263$

0.263
$0.011^{* * *}$

0.329

$0.034^{* * *}$

Dependent variable is a dummy variable indicating

a college degree:

Mother with college degree

Father with college degree

0.371 ***

0.214
$0.018^{*}$

610

610

0.262

0.093

$0.232 \quad 0.209$

$0.036^{* * *} \quad 0.042^{* * *} \quad 0.043^{* * *}$

0.310

$0.183^{*}$

Log family income in 1992

$0.372 \quad 0.313$

0.194

0.189

$0.062^{* * *}$

$0.014^{* * *}$

0.094
$0.009^{* * *}$

0.094
$0.009^{* * *}$

0.052

0.300

$0.052^{* * *}$

0.062

12721

12721

12721

383

383

383

610

Robust standard errors are in italics; ${ }^{*}$ significant at $10 \%$ level,${ }^{* *}$ significant at $5 \%$ level, ${ }^{* * *}$ significant at $1 \%$ level.

All regressions include controls for the child's age, gender, and number of siblings. 
Table 3: Testing for treatment differentials.

Years of schooling College degree

Means: ${ }^{a}$

Subsample of adoptees living in families with own birth siblings

$13.523 \quad 1.888$

$0.250 \quad 0.434$

Subsample of adoptees living in families without own birth siblings

$13.617 \quad 1.909$

$0.248 \quad 0.433$

Coefficient from regressions:

Adoptees living in families with own birth siblings

$-0.049 \quad 0.211$

$0.008 \quad 0.050$

Standard deviations and robust standard errors are in italics.

${ }^{a}$ Means and standard deviations are calculated for children of age 23 and older in an attempt

to measure completed schooling only.

${ }^{b}$ The coefficient comes from the fullest adoption specification presented in Table 2 when indicator whether adopted and own birth children are raised together in one family is added. 


\section{IZA Discussion Papers}

\begin{tabular}{|c|c|c|c|c|}
\hline No. & Author(s) & Title & Area & Date \\
\hline 636 & $\begin{array}{l}\text { M. Karanassou } \\
\text { H. Sala } \\
\text { J. D. Snower }\end{array}$ & $\begin{array}{l}\text { A Reappraisal of the Inflation-Unemployment } \\
\text { Tradeoff }\end{array}$ & 3 & $11 / 02$ \\
\hline 637 & $\begin{array}{l}\text { H. Bonin } \\
\text { W. Kempe } \\
\text { H. Schneider }\end{array}$ & $\begin{array}{l}\text { Household Labor Supply Effects of Low-Wage } \\
\text { Subsidies in Germany }\end{array}$ & 3 & $11 / 02$ \\
\hline 638 & $\begin{array}{l}\text { L. McLeod } \\
\text { M. R. Veall }\end{array}$ & $\begin{array}{l}\text { The Dynamics of Food Deprivation and Overall } \\
\text { Health: Evidence from the Canadian National } \\
\text { Population Health Survey }\end{array}$ & 2 & $11 / 02$ \\
\hline 639 & G. Saint-Paul & Are Intellectual Property Rights Unfair? & 3 & $11 / 02$ \\
\hline 640 & $\begin{array}{l}\text { J. Hartog } \\
\text { N. Jonker } \\
\text { H. van Ophem }\end{array}$ & $\begin{array}{l}\text { Dual Track or Academic Route for Auditors: } \\
\text { Does It Matter? }\end{array}$ & 6 & $11 / 02$ \\
\hline 641 & $\begin{array}{l}\text { J. Hartog } \\
\text { L. Diaz Serrano }\end{array}$ & $\begin{array}{l}\text { Earning Risk and Demand for Higher Education: } \\
\text { A Cross-Section Test for Spain }\end{array}$ & 2 & $11 / 02$ \\
\hline 642 & $\begin{array}{l}\text { J. Hartog } \\
\text { A. Zorlu }\end{array}$ & $\begin{array}{l}\text { The Effect of Immigration on Wages in Three } \\
\text { European Countries }\end{array}$ & 1 & $11 / 02$ \\
\hline 643 & $\begin{array}{l}\text { A. Björklund } \\
\text { M. Sundström }\end{array}$ & $\begin{array}{l}\text { Parental Separation and Children's Educational } \\
\text { Attainment: A Siblings Approach }\end{array}$ & 6 & $11 / 02$ \\
\hline 644 & $\begin{array}{l}\text { J. D. Brown } \\
\text { J. S. Earle }\end{array}$ & $\begin{array}{l}\text { Job Reallocation and Productivity Growth Under } \\
\text { Alternative Economic Systems and Policies: } \\
\text { Evidence from the Soviet Transition }\end{array}$ & 4 & $11 / 02$ \\
\hline 645 & $\begin{array}{l}\text { M. Karanassou } \\
\text { H. Sala } \\
\text { D. J. Snower }\end{array}$ & $\begin{array}{l}\text { Long-Run Inflation-Unemployment Dynamics: } \\
\text { The Spanish Phillips Curve and Economic Policy }\end{array}$ & 3 & $11 / 02$ \\
\hline 646 & $\begin{array}{l}\text { L. Graham } \\
\text { D. Snower }\end{array}$ & The Return of the Long-Run Phillips Curve & 3 & $11 / 02$ \\
\hline 647 & $\begin{array}{l}\text { C. Grund } \\
\text { D. Sliwka }\end{array}$ & Envy and Compassion in Tournaments & 1 & $11 / 02$ \\
\hline 648 & $\begin{array}{l}\text { C. Schnabel } \\
\text { T. Schank } \\
\text { J. Wagner }\end{array}$ & $\begin{array}{l}\text { Works Councils - Sand or Grease in the } \\
\text { Operation of German Firms? }\end{array}$ & 3 & $11 / 02$ \\
\hline 649 & $\begin{array}{l}\text { J. van Ours } \\
\text { J. Veenman }\end{array}$ & $\begin{array}{l}\text { From Parent to Child; Early Labor Market } \\
\text { Experiences of Second-Generation Immigrants } \\
\text { in the Netherlands }\end{array}$ & 1 & $11 / 02$ \\
\hline 650 & $\begin{array}{l}\text { H. Battu } \\
\text { P. J. Sloane }\end{array}$ & Overeducation and Ethnic Minorities in Britain & 2 & $11 / 02$ \\
\hline 651 & E. Schlicht & $\begin{array}{l}\text { Social Evolution, Corporate Culture, and } \\
\text { Exploitation }\end{array}$ & 3 & $11 / 02$ \\
\hline 652 & E. Plug & $\begin{array}{l}\text { How Do Parents Raise the Educational } \\
\text { Attainment of Future Generations? }\end{array}$ & 5 & $11 / 02$ \\
\hline
\end{tabular}

